\title{
Studies on the Metabolic Fate of NK-104, a New Inhibitor of HMG-CoA Reductase (4): Interspecies Variation in Laboratory Animals and Humans
}

\author{
Hideki Fujino, Junji Kojima, Youichi Yamada, Hiroyasu Kanda* and Hideki Kimata \\ Tokyo Research Laboratories, Kowa Company, Ltd., Tokyo; \\ *Central Research Laboratories, Nissan Chemical Industries, Ltd., Chiba
}

\begin{abstract}
Summary: NK-104 is a very potent competitive inhibitor of HMG-CoA reductase. The pharmacokinetic properties of NK-104 were evaluated after intravenous and/or oral administration to rats, rabbits, dogs, monkeys and humans. The plasma concentration of NK-104 showed triexponential elimination after intravenous administration, with a half-life of $4.0-5.3 \mathrm{~h}$ in all four animal species. The absorption was relatively rapid after the oral administration. The relationship between the dose and the AUC was linear at a relatively high dose range in the animal species. In humans, the correlation line was located between those of dogs and rats. High bioavailability (about $80 \%$ ) at a dose of $1 \mathrm{mg} / \mathrm{kg}$ was observed in all animal species except monkeys. These results indicated that the pharmacokinetic properties of NK-104 after oral administration in humans resembled those in dogs, suggesting that the BA of NK-104 is large in humans as well as dogs.

NK-104 was excreted mainly into feces via biliary route, and the renal handling was negligible in rats, dogs and humans. On the other hand NK-104 was excreted mainly into urine in rabbits, and was excreted poorly into urine and feces in monkeys.

The unchanged drug was excreted mainly in rat bile. Although several $\beta$-oxidation products as metabolites of NK-104 were detected, the levels of these metabolites were fairly low. In dogs, the major component in plasma, urine and feces after oral administration was the unchanged $\mathrm{NK}-104$. The $\beta$-oxidation products (M-5 and M-8) were also slightly detected only in dogs. In humans, the major components in plasma after repeated oral administration ( $2 \mathrm{mg} /$ day for 5 days) were $\mathrm{NK}-104$ and its lactone form.

These results suggest that NK-104 may be hardly metabolized in humans than in animal species.
\end{abstract}

\section{Key words: NK-104, HMG-CoA reductase inhibitor, Rat, Rabbit, Dog, Monkey, Human, Absorption, Excretion, Metabolism}

\section{Introduction}

In general, lowering low-density lipoprotein (LDL) cholesterol levels or increasing high-density (HDL) cholesterol levels in plasma reduces the risks of coronary heart disease and atherosclerosis. Based on the preclinical findings that NK-104 is a highly potent inhibitor of $\mathrm{HMG}-\mathrm{CoA}$ reductase, the rate limiting enzyme in cholesterol biosynthesis, ${ }^{1)}$ this agent is promising as a therapeutic drug for hyperlipidemia in humans. The ${ }^{14} \mathrm{C}$-labeled NK-104 was absorbed well from the intestinal tract after oral administration to rats and distributed in the liver at a high concentrations in the unchanged form. The drug distributed in the liver was mainly excreted in the bile and reabsorbed by entero-hepatic circulation. ${ }^{2)}$ In addition, the $\mathrm{C}_{\max }$ of $\mathrm{NK}-104$ reached a steady state within the 4 th dosing after repeated administration in rats. ${ }^{3)}$ These pharmacokinetic profiles suggest that $\mathrm{NK}-104$ has selectivity for the liver and long acting $\mathrm{HMG}-\mathrm{CoA}$ reductase inhibitory effects.
The toxicity and/or the efficacy of a drug in animals or humans are often related to its pharmacokinetics and metabolism. In particular, considerable attention has been paid to interspecies variation in the pharmacokinetics and metabolism. This study examined basic pharmacokinetics of NK-104 in four animal species, rats, rabbits, monkeys, and dogs, and in humans. We also carried out a series of metabolic studies involving bile in rats, feces in dogs, and plasma and urine in dogs and humans.

\section{Materials and Methods}

\section{Materials}

The NK-104 (monocalcium bis $[(3 \mathrm{R}, 5 \mathrm{~S}, 6 \mathrm{E})-7-[2-$ cyclopropyl-4-(4-fluorophenyl) -3-quinolyl $] 3.5-$ dihydroxy-6-heptenoate]) and its metabolites which were determined by NMR and LC-MS spectrometry in the bile of animals after an intravenous infusion ${ }^{4)}(\mathrm{NK}-104$ lactone, M-2, M-3, M-4, M-5, M-6, M-7, M-8, M-9, M-10 and M-11) were synthesized by Nissan Chemical Industries, Ltd. (Funabashi, Japan). The structures of 


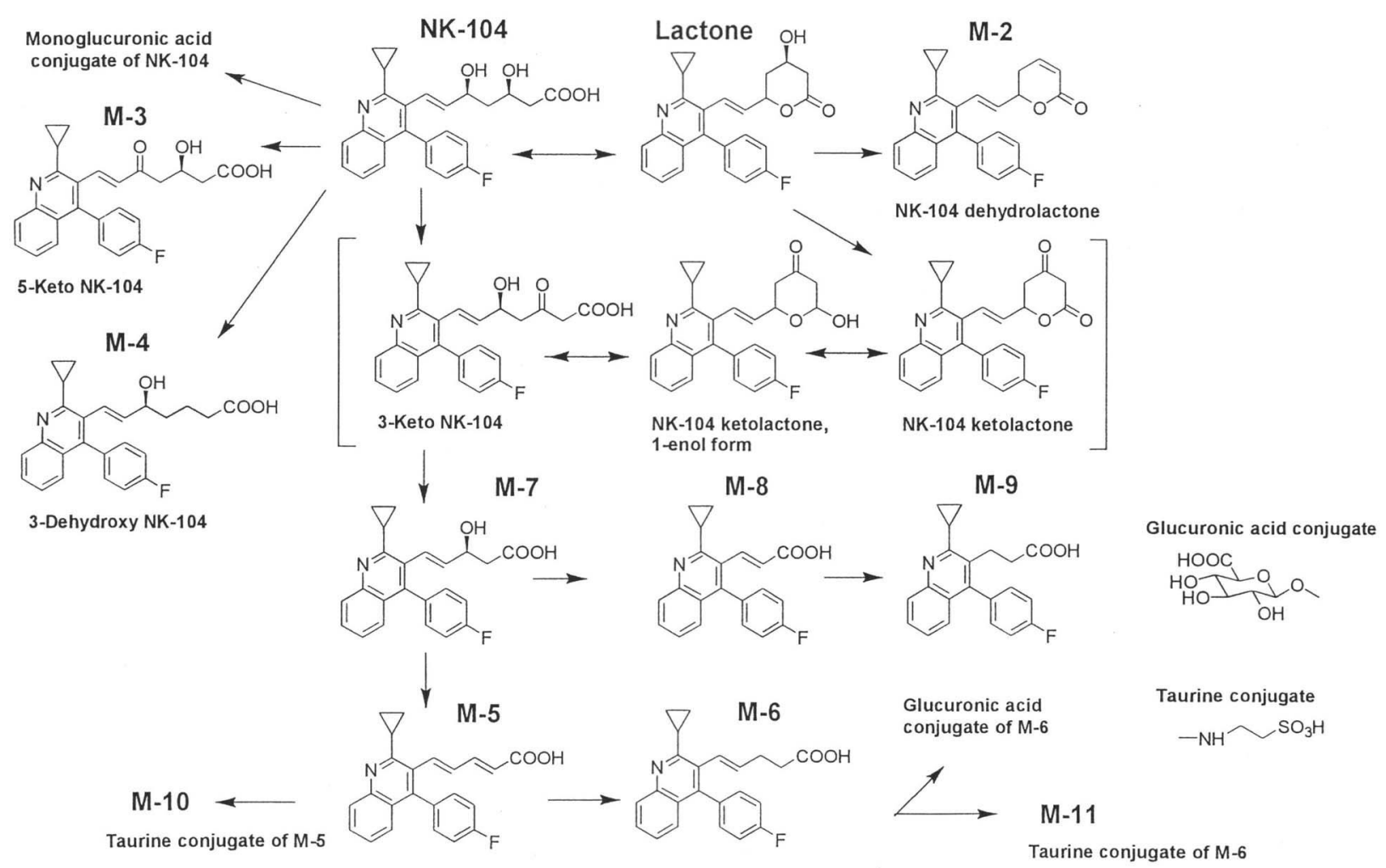

Fig. 1 Postulated metabolic pathways of NK-104

NK-104 and its metabolites are shown in Fig. 1. All other solvents and chemicals were obtained commercially, and were of HPLC grade or extra pure grade.

\section{Animals}

Wistar strain (specific pathogen-free) male rats, weighing about $200 \mathrm{~g}$, JW strain male rabbits, weighing about $2.5 \mathrm{~kg}$, HRA-male beagle dogs, weighing about $10 \mathrm{~kg}$ (Japan Laboratory Animal Inc. Tokyo, Japan) and male cynomolgus monkeys, weighing about $4 \mathrm{~kg}$ (Philippines born, Japan SLC. Inc. Shizuoka, Japan) were used. The rats and rabbits were acclimatized for at least 4 days, and all animals were kept in a controlled care room at the temperature of $23 \pm 2^{\circ} \mathrm{C}$ and a relative humidity of $60 \pm 10 \%$. All animals were maintained on laboratory chow diets and were fasted overnight prior to the drug administration, but had free access to water. Three or four animals were assigned to each test group.

\section{Pharmacokinetic Study in Animals}

\section{1) Intravenous Administration Study}

The dosage form of NK-104 was prepared as a solution in physiological saline at a range of $0.1-1 \mathrm{mg} / \mathrm{m} l$ for intravenous administration. The rabbits and dogs were intravenously given $0.1 \mathrm{mg} / \mathrm{kg}$, the monkeys and rats were intravenously given 0.3 and $1 \mathrm{mg} / \mathrm{kg}$ of $\mathrm{NK}-104$, respectively. The dose levels were quoted from the minimum dose of oral administration and our previous study. ${ }^{2)}$ The intravenous bolus injection was made in the front leg vein of dogs, the femoral vein of monkeys, the ear vein of rabbits and the tail vein of rats. Blood samples were withdrawn from the jugular vein of rats, from the ear vein of rabbits, from the front leg vein of dogs and from the femoral vein in monkeys at the indicated times. Plasma was separated after centrifugation of blood sample. The plasma samples were stored at $-20^{\circ} \mathrm{C}$ until analyzed.

\section{2) Oral Administration Study}

NK-104 was prepared as a suspension in $0.5 \%$ sodium carboxymethyl cellulose solution at a range of $0.1-5$ $\mathrm{mg} / \mathrm{m} l$ for oral administration. The rabbits and dogs were given $\mathrm{NK}-104$ in single oral administration of 0.1 , 0.3 or $1 \mathrm{mg} / \mathrm{kg}$. The rats and monkeys were given $\mathrm{NK}^{-}$ 104 at $0.3,1$ or $3 \mathrm{mg} / \mathrm{kg}$. The collection of blood samples was carried out in the same manner as for the intravenous administration.

\section{3) Excretion of $\mathrm{NK}-104$ in Urine and Feces}

Rats were housed individually in glass metabolic cages (Metabolica ${ }^{\circledR}$; Sugiyamagen Iriki, Tokyo, Japan) after intravenous or oral administration of NK-104. The other animals were maintained individually in stainless steel metabolic cages. Urine and feces were collected separately every $24 \mathrm{~h}$ up to 72 or $96 \mathrm{~h}$ after the administration. Each urinary sample was diluted with water. Each fecal sample was homogenized with water. Aliquots $(0.5 \mathrm{ml}$ or $0.5 \mathrm{~g})$ of urine and fecal homogenates were stored at $-20^{\circ} \mathrm{C}$ until analyzed. 


\section{Biliary Metabolites in Rats}

Rats were surgically prepared with common bile duct cannulae under ether anesthesia. After awakening, NK104 was orally administered at a dose of $1 \mathrm{mg} / \mathrm{kg}$ and each animal was housed individually in a Bollman's cage (Natsume Seisakusyo, Tokyo, Japan). The bile was continuously collected for $24 \mathrm{~h}$ in the dark to prevent the degradation of biliary metabolites. The biliary samples were stored at $-20^{\circ} \mathrm{C}$ until analysis.

\section{Plasma, Urinary and Fecal Metabolites in Dogs}

The plasma, urinary and fecal metabolites were investigated in dogs after intravenous administration of NK104 at a dose of $0.1 \mathrm{mg} / \mathrm{kg}$ and oral administration at 1 $\mathrm{mg} / \mathrm{kg}$ and $10 \mathrm{mg} / \mathrm{kg}$. The administration procedure and the collection of biological samples were carried out as described above. Aliquots of plasma, urinary and fecal samples were stored at $-20^{\circ} \mathrm{C}$ until analysis.

\section{Repeated Administration of NK-104 in Humans}

Five healthy male volunteers (age, 22-24 years) received repeated oral administrations of $\mathrm{NK}-104$ at a dose of $2 \mathrm{mg}$ as a tablet once a day for five days. In this study, not only the plasma concentration of NK-104 but also the plasma and urinary metabolites of NK-104 were investigated. The protocol was approved by the NizaShiki Central Hospital Ethical Committee, and the subjects had given their informed consent. Blood samples were taken via an antecubital vein at various times up to $48 \mathrm{~h}$ after the final administration for the parent drug and its lactone assays, and at 1.5, 6 and $24 \mathrm{~h}$ on day 1 and day 5 for the metabolites assay. Urine samples were collected every $24 \mathrm{~h}$ after daily administration. Aliquots of plasma and urinary samples were stored at $-20^{\circ} \mathrm{C}$ until analysis.

\section{Enzymatic Hydrolysis}

To confirm the presence of conjugates of NK-104 and its metabolites, the urinary, fecal and biliary samples were treated with enzymatic hydrolysis. The incubations of the urinary, fecal and biliary samples were carried out with $\beta$-glucuronidase/arylsulfatase (5000 fishman units and 80 units) at $37^{\circ} \mathrm{C}$. The amounts of conjugates were calculated by subtracting the concentration of enzyme-untreated samples.

\section{Analytical Methods}

\section{1) Preparation of Standard Solution}

Quantitative analysis of NK-104 and NK-104 lactone in the biological samples was performed by a column switching-HPLC method described in our previous report. ${ }^{5)}$ The other NK-104 metabolites, M-2 (NK-104 dehydrolactone), M-3 (5-keto NK-104), M-4 (3-dehydroxy NK-104), M-5 (pentadienoic acid derivative), M-6 (pentenoic acid derivative), M-7 (hydroxypentenoic acid derivative), M-8 (propenoic acid derivative), M-9 (propanoic acid derivative), M-10 (taurine conjugate of pentadienoic acid derivative) and M-11 (taurine conjugate of pentenoic acid derivative) were measured by the five methods as described in Table I. The

Table I Analytical conditions for the determination of NK-104 and its metabolites

\begin{tabular}{|c|c|c|c|c|c|}
\hline Analytes & $\begin{array}{c}\text { Method-1 } \\
\text { NK-104, lactone, } \\
\text { M-4 }\end{array}$ & $\begin{array}{c}\text { Method-2 } \\
\text { M-10, M-11 }\end{array}$ & $\begin{array}{c}\text { Method-3 } \\
\text { M-2, M-5, M-6 }\end{array}$ & $\begin{array}{l}\text { Method-4 } \\
\text { M-3, M-7 }\end{array}$ & $\begin{array}{l}\text { Method-5 } \\
\text { M-8, M-9 }\end{array}$ \\
\hline \multicolumn{6}{|l|}{$\begin{array}{l}\text { Chromatographic } \\
\text { conditions }\end{array}$} \\
\hline \multicolumn{6}{|l|}{ Pre-separation } \\
\hline Pre-column: & $\begin{array}{c}\text { Cosmosil }_{5} \mathrm{C}_{18} \\
(150 \mathrm{~mm} \times 4.6 \mathrm{~mm})\end{array}$ & $\begin{array}{c}\text { Cosmosil }_{5} \mathrm{C}_{18} \\
(150 \mathrm{~mm} \times 4.6 \mathrm{~mm})\end{array}$ & $\begin{array}{c}\text { Cosmosil }_{5} \mathrm{C}_{18} \\
(150 \mathrm{~mm} \times 4.6 \mathrm{~mm})\end{array}$ & $\begin{array}{c}\operatorname{Cosmosil~}_{5} \mathrm{C}_{18} \\
(150 \mathrm{~mm} \times 4.6 \mathrm{~mm})\end{array}$ & $\begin{array}{c}\operatorname{Cosmosil}_{3} \mathrm{C}_{18} \\
(100 \mathrm{~mm} \times 4.6 \mathrm{~mm})\end{array}$ \\
\hline Mobile phase: & $\begin{array}{c}0.2 \mathrm{M} \text { acetate buffer } \\
(\mathrm{pH} 4) / \mathrm{CH}_{3} \mathrm{CN} \\
(50: 50)\end{array}$ & $\begin{array}{c}0.1 \mathrm{M} \text { acetic acid with } \\
1.5 \mathrm{mM} \text { TBAS/ } \\
\mathrm{CH}_{3} \mathrm{CN}(65: 35)\end{array}$ & $\begin{array}{l}0.2 \mathrm{M} \text { acetic acid/ } \\
\mathrm{CH}_{3} \mathrm{CN}(50: 50)\end{array}$ & $\begin{array}{l}0.2 \mathrm{M} \text { acetic acid/ } \\
\mathrm{CH}_{3} \mathrm{CN}(60: 40)\end{array}$ & $\begin{array}{c}0.2 \mathrm{M} \text { acetate buffer } \\
(\mathrm{pH} 4.3) / \mathrm{CH}_{3} \mathrm{CN} \\
(55: 45)\end{array}$ \\
\hline Flow-rate: & $1 \mathrm{ml} / \mathrm{min}$ & $1 \mathrm{~m} l / \mathrm{min}$ & $1 \mathrm{ml} / \mathrm{min}$ & $1 \mathrm{~m} l / \mathrm{min}$ & $0.8 \mathrm{ml} / \mathrm{min}$ \\
\hline $\begin{array}{l}\text { Column switching: about } \\
\text { (after injection) }\end{array}$ & $\begin{array}{l}10-12 \mathrm{~min} \text { and } \\
\text { about } 24-27 \mathrm{~min}\end{array}$ & $\begin{array}{l}\text { about } 6-7 \mathrm{~min} \text { and } \\
\text { about } 18-21 \mathrm{~min}\end{array}$ & $\begin{array}{l}\text { about } 8-9 \mathrm{~min} \text { and } \\
\text { about } 15-18 \mathrm{~min}\end{array}$ & $\begin{array}{l}\text { about } 6-8 \mathrm{~min} \text { and } \\
\text { about } 16-18 \mathrm{~min}\end{array}$ & about $15-18 \mathrm{~min}$ \\
\hline \multicolumn{6}{|l|}{ Analytical separation } \\
\hline Column: & $\begin{array}{c}\operatorname{Cosmosil~}_{5} \mathrm{C}_{18} \\
(150 \mathrm{~mm} \times 4.6 \mathrm{~mm})\end{array}$ & $\begin{array}{c}\operatorname{Cosmosil~}_{5} \mathrm{C}_{18} \\
(150 \mathrm{~mm} \times 4.6 \mathrm{~mm})\end{array}$ & $\begin{array}{c}\text { Cosmosil }_{5} \mathrm{C}_{18} \\
(150 \mathrm{~mm} \times 4.6 \mathrm{~mm})\end{array}$ & $\begin{array}{c}\text { Cosmosil }_{5} \mathrm{C}_{18} \\
(150 \mathrm{~mm} \times 4.6 \mathrm{~mm})\end{array}$ & $\begin{array}{c}\text { Cosmosil }_{5} \mathrm{C}_{18} \\
(150 \mathrm{~mm} \times 4.6 \mathrm{~mm})\end{array}$ \\
\hline Mobile phase: & $\begin{array}{l}0.2 \mathrm{M} \text { acetic acid/ } \\
\mathrm{CH}_{3} \mathrm{CN}(50: 50)\end{array}$ & $\begin{array}{c}0.1 \mathrm{M} \text { acetate buffer } \\
\text { (pH5) with } 1.5 \mathrm{mM} \\
\text { TBAS } / \mathrm{CH}_{3} \mathrm{CN} \\
(50: 50)\end{array}$ & $\begin{array}{c}0.2 \mathrm{M} \text { acetate buffer } \\
(\mathrm{pH} 4.2) / \mathrm{CH}_{3} \mathrm{CN} \\
(50: 50)\end{array}$ & $\begin{array}{c}0.2 \mathrm{M} \text { acetate buffer } \\
(\mathrm{pH} 3) / \mathrm{CH}_{3} \mathrm{CN} \\
(50: 50)\end{array}$ & $\begin{array}{c}0.2 \mathrm{M} \text { acetate buffer } \\
(\mathrm{pH} 5) / \mathrm{CH}_{3} \mathrm{CN} \\
(50: 50)\end{array}$ \\
\hline Heartcut time: & $2.6 \mathrm{~min}$ & $1.2 \mathrm{~min}$ & $1.5 \min$ & $1.4 \mathrm{~min}$ & $3 \min$ \\
\hline (after valve rotation) & $2.3 \mathrm{~min}$ & $2.8 \mathrm{~min}$ & $2.4 \mathrm{~min}$ & $1.6 \mathrm{~min}$ & \\
\hline Flow-rate: & $1 \mathrm{ml} / \mathrm{min}$ & $1 \mathrm{ml} / \mathrm{min}$ & $1 \mathrm{ml} / \mathrm{min}$ & $1 \mathrm{ml} / \mathrm{min}$ & $0.8 \mathrm{ml} / \mathrm{min}$ \\
\hline Total run-time: & $50 \mathrm{~min}$ & $30 \mathrm{~min}$ & $35 \mathrm{~min}$ & $30 \mathrm{~min}$ & $30 \mathrm{~min}$ \\
\hline
\end{tabular}


stock solutions of NK-104, M-3, M-4, M-5, M-6, M-7, $\mathrm{M}-8, \mathrm{M}-9, \mathrm{M}-10$ and $\mathrm{M}-11$ were prepared in water, whereas those of M-2 and NK-104 lactone were prepared in methyl tert- butyl ether (MTBE). The stock solutions of NK-104 and its metabolites were diluted with water or MTBE to appropriate concentrations for standard preparation. These solutions were stored in the dark at $4^{\circ} \mathrm{C}$.

\section{2) Sample Preparation}

In Methods 1, 3, 4 and 5, the internal standards were added to biological samples in a colored tube, and then 1 $M$ potassium dihydrogenphosphate was added. These mixtures were extracted with $6 \mathrm{~m} l$ of MTBE and subsequently centrifuged at approximately $700 \mathrm{~g}$. In the Method 1, the organic layer was transferred to another colored tube and then diazomethane-ether solution $(0.5$ $\mathrm{m} l$ ) was added. After $0.5 \mathrm{~h}$, excessive diazomethane was degraded by the addition of $1 \mathrm{M}$ potassium dihydrogenphosphate $(2 \mathrm{ml})$, and the organic layer was evaporated to dryness under a gentle stream of nitrogen at $40^{\circ} \mathrm{C}$. In the Methods 3,4 and 5 , the organic layer was also transferred to another colored tube and was evaporated to dryness. In the Method 2, the unextractable fractions of biological samples were further extracted by chloroform after addition of $50 \mathrm{mM}$ tetrabutylammonium hydrogen sulfate (TBAS). After the extraction, the organic layer was transferred to another colored tube and was evaporated to dryness. Each residue was dissolved in $150 \mu l$ of the mobile phase, and an aliquot of $80 \mu l$ was injected into an HPLC system.

\section{3) Column Switching-HPLC}

The HPLC-chromatographic system (LC-6A or 10A series, Shimadzu, Kyoto, Japan) consisted of two pumps, an automatic sample injector and a high-pressure six-port valve. A UV detector linked to a data system was used for data acquisition and storage. The chromatographic signals were monitored at $250 \mathrm{~nm}$ for the quantification of NK-104 and its metabolites. The column switching according to valve operation was carried out automatically by the SCL-6A or a $10 \mathrm{~A}$ controller programed valve rotation time. Two columns were used for the pre-separation and analytical separation, respectively. The injected samples were first separated on the pre-column, and the flow path was switched to the analytical column, transferring analytes from the pre-column to the analytical column. The chromatographic conditions of column switching are shown in Table I.

\section{Calculations}

The pharmacokinetic parameters were calculated from the individual plasma concentration-time curve of NK-104 and its metabolites in each animal species and humans. The plasma concentration curves of NK-104 after intravenous administration could be adequately described by an exponential equation, $\mathrm{Cp}=\mathrm{P} e^{-\pi \mathrm{t}}+\mathrm{A} e^{-\alpha \mathrm{t}}+$ $\mathrm{B} e^{-\beta \mathrm{t}}$. The observed data were fitted in the triexponen- tial equation using a nonlinear least-squares curve fitting program. ${ }^{6)}$ The elimination half-life $\left(t_{1 / 2}\right)$ value was estimated by using the least square method of actual data. The area under the plasma concentration-time curve (AUC) value was obtained by the trapezoidal rule. The plasma clearance (Clp) was estimated by the relationship of dose/AUC. After oral administration, the maximum concentration $\left(\mathrm{C}_{\max }\right)$ of analyte was read directly from the concentration-time data. The bioavailability (BA) was calculated from the dose-normalized AUC obtained from oral and intravenous administrations. The excretion of NK-104 and its metabolites in urine, feces and bile was corrected to the \% of dose. Each value represents the mean \pm S.E. of 3-6 animals or humans.

\section{Results}

\section{Pharmacokinetics Studies}

1) Intravenous Administration in Animals (Fig. 2, Table II)

The plasma concentration of $\mathrm{NK}-104$ after intravenous administration of $1 \mathrm{mg} / \mathrm{kg}$ to rats, $0.1 \mathrm{mg} / \mathrm{kg}$ to rabbits and dogs, and $0.3 \mathrm{mg} / \mathrm{kg}$ to monkeys showed a triexponential elimination with half-life values for the terminal phase $\left(t_{1 / 2}\right)$ of $3.97,5.06,4.60$ and $5.31 \mathrm{~h}$, respectively. The plasma clearance (Clp) values in rats, rabbits, dogs and monkeys were 11.6, 1.0, 5.8 and 10.3 $\mathrm{ml} / \mathrm{min} / \mathrm{kg}$, and the distribution volume of steady-state (Vss) values were $1.34,0.38,0.97$ and $1.53 \mathrm{~L} / \mathrm{kg}$, respectively. The ratios of blood to plasma concentration
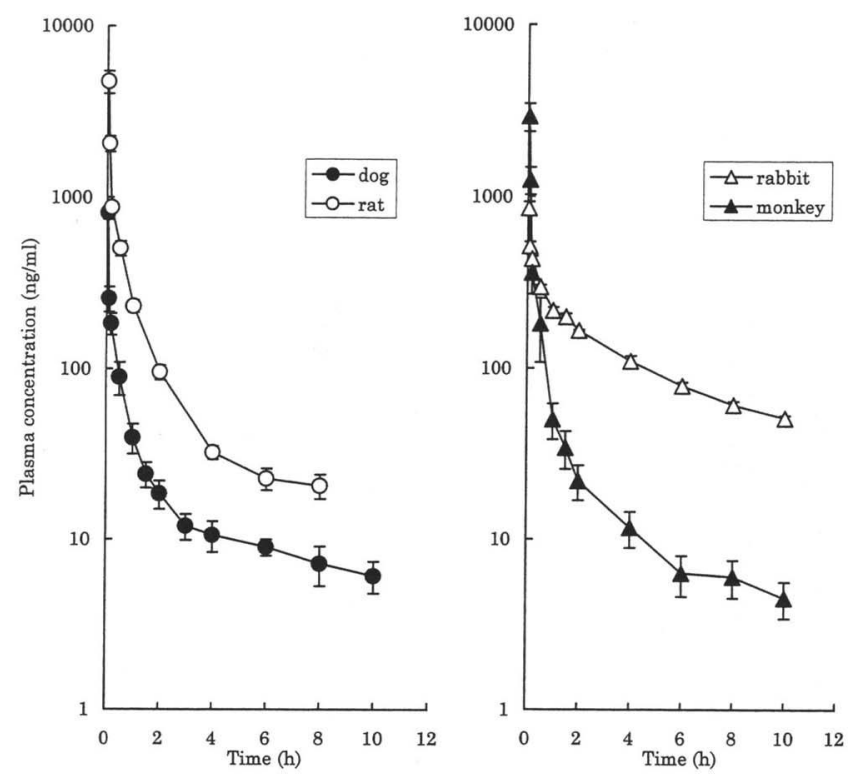

Fig. 2 Mean plasma concentration of NK-104 in different species after intravenous administration $\mathrm{NK}-104$ was given to rats $(\bigcirc)$ at a dose of $1 \mathrm{mg} / \mathrm{kg}$, dogs ( at a dose of $0.1 \mathrm{mg} / \mathrm{kg}$, rabbits $(\triangle)$ at a dose of $0.1 \mathrm{mg} / \mathrm{kg}$ and monkeys $(\mathbf{\Lambda})$ at a dose of 0.3 $\mathrm{mg} / \mathrm{kg}$.

Each point represents the mean \pm S.E of three or four animals. 
Table II Pharmacokinetic parameters obtained from a three-compartment model after intravenous administration of NK-104 in different species

\begin{tabular}{|c|c|c|c|c|c|}
\hline \multicolumn{2}{|c|}{ Parameter } & \multirow{2}{*}{$\begin{array}{c}\begin{array}{c}\text { Rat } \\
(\mathrm{n}=4)\end{array} \\
1\end{array}$} & \multirow{2}{*}{$\begin{array}{c}\begin{array}{c}\text { Rabbit } \\
(\mathrm{n}=4)\end{array} \\
0.1\end{array}$} & \multirow{2}{*}{$\frac{\underset{(\mathrm{Dog}}{(\mathrm{n}=4)}}{0.1}$} & \multirow{2}{*}{$\begin{array}{c}\begin{array}{c}\text { Monkey } \\
(\mathrm{n}=3)\end{array} \\
0.3\end{array}$} \\
\hline Dose & $(\mathrm{mg} / \mathrm{kg})$ & & & & \\
\hline B.W. & $(\mathrm{kg})$ & $0.20 \pm 0.00$ & $2.51 \pm 0.06$ & $10.13 \pm 0.27$ & $3.99 \pm 0.04$ \\
\hline$P$ & $(\mathrm{ng} / \mathrm{m} l)$ & $12700 \pm 2300$ & $3924 \pm 1926$ & $5175 \pm 2418$ & $4868 \pm 746$ \\
\hline$\pi$ & $\left(\min ^{-1}\right)$ & $0.507 \pm 0.033$ & $0.91 \pm 0.10$ & $1.09 \pm 0.26$ & $0.325 \pm 0.030$ \\
\hline A & $(\mathrm{ng} / \mathrm{m} l)$ & $1180 \pm 80$ & $343 \pm 59$ & $251 \pm 49$ & $186 \pm 56$ \\
\hline$\alpha$ & $\left(\min ^{-1}\right)$ & $0.0328 \pm 0.004$ & $0.0344 \pm 0.0083$ & $0.0433 \pm 0.0087$ & $0.0268 \pm 0.0059$ \\
\hline B & $(\mathrm{ng} / \mathrm{m} l)$ & $93.5 \pm 24.1$ & $194 \pm 19$ & $19.4 \pm 5.2$ & $17.8 \pm 3.0$ \\
\hline$\beta$ & $\left(\min ^{-1}\right)$ & $0.0036 \pm 0.001$ & $0.0024 \pm 0.0003$ & $0.0026 \pm 0.0003$ & $0.0024 \pm 0.0005$ \\
\hline & (h) & $3.97 \pm 1.10$ & $5.06 \pm 0.61$ & $4.60 \pm 0.41$ & $5.31 \pm 1.00$ \\
\hline AUC & $u g \cdot h / m l)$ & $1.46 \pm 0.10$ & $1.62 \pm 0.08$ & $0.29 \pm 0.02$ & $0.50 \pm 0.06$ \\
\hline Clp (m & $/ \mathrm{min} / \mathrm{kg})$ & $11.6 \pm 0.8$ & $1.04 \pm 0.05$ & $5.79 \pm 0.41$ & $10.25 \pm 1.18$ \\
\hline MRT & (h) & $1.94 \pm 0.55$ & $6.22 \pm 0.65$ & $2.79 \pm 0.08$ & $2.39 \pm 0.74$ \\
\hline Vss & $(\mathrm{L} / \mathrm{kg})$ & $1.34 \pm 0.39$ & $0.38 \pm 0.03$ & $0.97 \pm 0.08$ & $1.53 \pm 0.52$ \\
\hline \multicolumn{6}{|c|}{ Lactone } \\
\hline $\mathrm{C}_{\max }$ & $(\mathrm{ng} / \mathrm{m} l)$ & n.d. & $6.9 \pm 1.1$ & $11.8 \pm 2.6$ & $118 \pm 33$ \\
\hline $\mathrm{T}_{\max }$ & (h) & - & $0.38 \pm 0.21$ & $2.00 \pm 0.35$ & $0.03 \pm 0.00$ \\
\hline$t_{1 / 2}$ & (h) & - & $9.69 \pm 1.03$ & $6.93 \pm 1.16$ & $1.95 \pm 0.22$ \\
\hline
\end{tabular}

The data are expressed as mean \pm S.E. of three or four different species. n.d., not detected.

(RBP) up to $2 \mathrm{~h}$ after administration showed an almost constant value of approximately 0.6 in all species, indicating that the distribution of $\mathrm{NK}-104$ into erythrocytes was small. Although the NK-104 lactone in plasma after administration was not found in rats, this metabolite was detected in the other three species. The species difference in pharmacokinetic parameters of
NK-104 lactone was also observed not only in the $\mathrm{T}_{\max }$ values $(0.03-2.00 \mathrm{~h})$ but also $\mathrm{C}_{\max }$ values $(7,12$ and 118 $\mathrm{ng} / \mathrm{ml}$ in rabbits an dogs at $0.1 \mathrm{mg} / \mathrm{kg}$ and monkeys at $0.3 \mathrm{mg} / \mathrm{kg}$, respectively).

2) Oral Administration in Animals (Fig. 3, Table III)

After oral administration at a dose of $0.3,1$ and $3 \mathrm{mg} /$
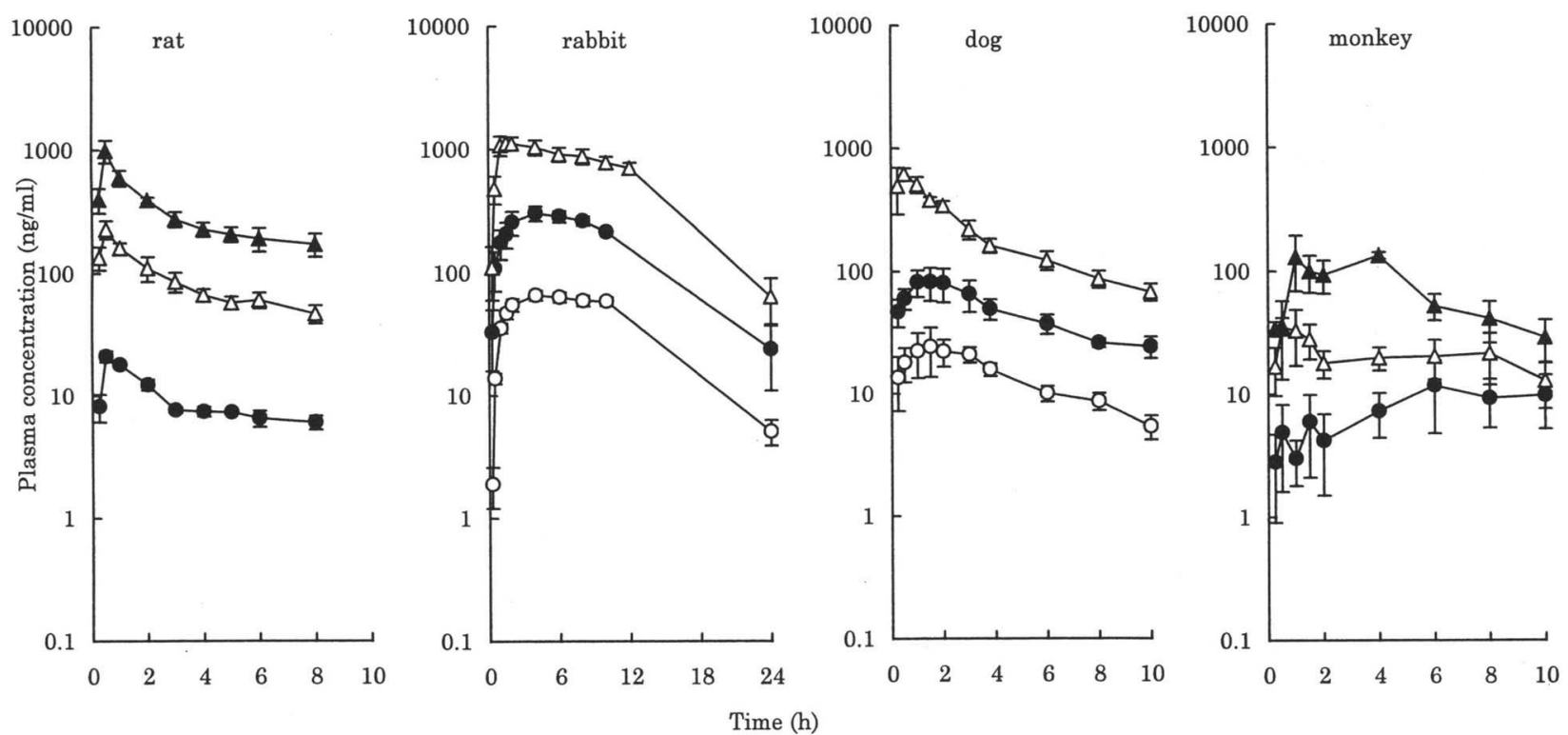

Fig. 3 Mean plasma concentration of NK-104 in different species after oral administration at a dose of $0.1 \mathrm{mg} / \mathrm{kg}(\bigcirc), 0.3$ $\mathrm{mg} / \mathrm{kg}(\bigcirc), 1 \mathrm{mg} / \mathrm{kg}(\triangle)$ and $3 \mathrm{mg} / \mathrm{kg}(\mathbf{\Delta})$

Each point represents the mean \pm S.E of three or four animals. 
Table III Pharmacokinetic parameters after oral administration of NK-104 in different species

\begin{tabular}{|c|c|c|c|c|c|c|c|c|c|}
\hline Animal & $\begin{array}{c}\text { Dose } \\
(\mathrm{mg} / \mathrm{kg})\end{array}$ & $\begin{array}{l}\mathrm{T}_{\max } \\
(\mathrm{h})\end{array}$ & $\underset{(\mathrm{ng} / \mathrm{m} l)}{\mathrm{C}_{\max }}$ & $\begin{array}{l}t_{1 / 2} \\
(h)\end{array}$ & $\underset{(\mu \mathrm{g} \cdot \mathrm{h} / \mathrm{m} l)}{\mathrm{AUC}}$ & $\begin{array}{l}\mathrm{BA} \\
(\%)\end{array}$ & $\begin{array}{l}\mathrm{T}_{\max } \\
(\mathrm{h})\end{array}$ & $\begin{array}{c}\text { Lactone } \\
\mathrm{C}_{\max } \\
(\mathrm{ng} / \mathrm{m} l)\end{array}$ & $\begin{array}{l}\mathrm{t}_{1 / 2} \\
(\mathrm{~h})\end{array}$ \\
\hline \multirow{3}{*}{$\begin{array}{l}\text { Rat } \\
(n=4)\end{array}$} & 0.3 & $0.67 \pm 0.17$ & $22 \pm 2$ & $7.68 \pm 0.47$ & $0.14 \pm 0.01$ & 31 & - & n.d. & - \\
\hline & 1.0 & $0.88 \pm 0.38$ & $231 \pm 35$ & $6.73 \pm 1.05$ & $1.17 \pm 0.22$ & 80 & - & n.d. & - \\
\hline & 3.0 & $0.50 \pm 0.00$ & $911 \pm 210$ & $6.47 \pm 0.94$ & $3.95 \pm 0.65$ & 91 & - & n.d. & - \\
\hline \multirow{3}{*}{$\begin{array}{l}\text { Rabbit } \\
(\mathrm{n}=4)\end{array}$} & 0.1 & $6.00 \pm 1.40$ & $69 \pm 5$ & $4.24 \pm 0.56$ & $1.03 \pm 0.07$ & 64 & $8.50 \pm 1.50$ & $1.0 \pm 0.2$ & * \\
\hline & 0.3 & $4.50 \pm 1.30$ & $314 \pm 33$ & $4.67 \pm 1.25$ & $4.34 \pm 0.19$ & 89 & $5.50 \pm 0.96$ & $4.8 \pm 0.4$ & $25.4 \pm 4.3$ \\
\hline & 1.0 & $1.50 \pm 0.29$ & $1184 \pm 154$ & $3.91 \pm 0.73$ & $15.67 \pm 1.55$ & 97 & $4.25 \pm 2.02$ & $21.1 \pm 3.8$ & $16.9 \pm 5.9$ \\
\hline \multirow{3}{*}{$\begin{array}{l}\text { Dog } \\
(\mathrm{n}=4)\end{array}$} & 0.1 & $1.94 \pm 0.66$ & $29 \pm 9$ & $3.95 \pm 0.41$ & $0.17 \pm 0.03$ & 58 & $4.00 \pm 0.70$ & $7.1 \pm 1.2$ & $5.51 \pm 0.46$ \\
\hline & 0.3 & $2.50 \pm 1.19$ & $93 \pm 24$ & $4.26 \pm 0.50$ & $0.63 \pm 0.13$ & 71 & $2.75 \pm 0.63$ & $26.6 \pm 3.7$ & $5.55 \pm 0.39$ \\
\hline & 1.0 & $0.56 \pm 0.16$ & $724 \pm 131$ & $4.32 \pm 0.27$ & $2.57 \pm 0.27$ & 88 & $2.50 \pm 0.29$ & $117 \pm 12$ & $7.16 \pm 0.97$ \\
\hline \multirow{3}{*}{$\begin{array}{l}\text { Monkey } \\
(\mathrm{n}=3)\end{array}$} & 0.3 & $2.67 \pm 1.69$ & $17 \pm 5$ & $4.50 \pm 0.54$ & $0.16 \pm 0.06$ & 31 & $6.67 \pm 1.76$ & $2.6 \pm 1.7$ & $11.21^{* *}$ \\
\hline & 1.0 & $3.17 \pm 2.42$ & $61 \pm 11$ & $4.54 \pm 0.76$ & $0.31 \pm 0.07$ & 18 & $2.33 \pm 0.88$ & $9.4 \pm 3.1$ & $5.24 \pm 1.56$ \\
\hline & 3.0 & $2.17 \pm 0.93$ & $165 \pm 43$ & $3.66 \pm 0.37$ & $0.85 \pm 0.16$ & 17 & $2.67 \pm 0.67$ & $21.3 \pm 6.2$ & $4.87 \pm 1.03$ \\
\hline
\end{tabular}

The data are expressed as mean \pm S.E. of three or four different species.

n.d., not detected.

* : unable to calculate.

** $: \mathrm{n}=2$.

$\mathrm{kg}$ to rats, NK-104 was rapidly absorbed and reached maximum levels within $1 \mathrm{~h}$ independent of the dosage. The $\mathrm{C}_{\max }$ values increased more than dose-proportionally in the dose range. The increase in AUC was largely dose-proportional up to a dose of $1 \mathrm{mg} / \mathrm{kg}$, but doseproportional from 1 to $3 \mathrm{mg} / \mathrm{kg}$. The plasma concentrations of NK-104 exhibited a biexponential decrease, and the $t_{1 / 2}$ in the last phase was about $7 \mathrm{~h}$ at a dose of $1 \mathrm{mg} /$ $\mathrm{kg}$. The BA in rats was $80 \%$ at a dose of $1 \mathrm{mg} / \mathrm{kg}$. In addition, the NK-104 lactone in the rat plasma was not detected.

In rabbits, the $\mathrm{C}_{\max }$ and $\mathrm{AUC}$ values of NK-104 increased linearly in the tested dose range of 0.1 to $1 \mathrm{mg} /$ $\mathrm{kg}$. Although the plasma concentrations of NK-104 were declined moderately up to $10 \mathrm{~h}$ after administration, thereafter its elimination $t_{1 / 2}$ was about $4 \mathrm{~h}$ at a dose of $1 \mathrm{mg} / \mathrm{kg}$. The BA in rabbits was $97 \%$. The $\mathrm{C}_{\max }$ of NK-104 lactone as a metabolite after administration at $1 \mathrm{mg} / \mathrm{kg}$ was $21.1 \mathrm{ng} / \mathrm{ml}$, only $1 / 56$ of the $C_{\max }$ of NK-104.

In dogs, the $\mathrm{C}_{\max }$ and AUC values of the parent drug increased dose-proportionally as they did in rabbits. The plasma concentrations of NK-104 exhibited an exponential decrease, and its $\mathrm{t}_{1 / 2}$ was about $4 \mathrm{~h}$ in the $1 \mathrm{mg} / \mathrm{kg}$ administration. The $\mathrm{BA}$ in dogs was $88 \%$ at a dose of 1 $\mathrm{mg} / \mathrm{kg}$. The $\mathrm{C}_{\max }$ of NK-104 lactone after administration at $1 \mathrm{mg} / \mathrm{kg}$ was $117 \mathrm{ng} / \mathrm{ml}$, about $1 / 6$ compared with the $\mathrm{C}_{\max }$ of $\mathrm{NK}-104$.

In monkeys, the $\mathrm{C}_{\max }$ and $\mathrm{AUC}$ values of the parent drug also increased linearly in the dose range of 0.3 to 3 $\mathrm{mg} / \mathrm{kg}$, and the $\mathrm{t}_{1 / 2}$ values were similar to those of the rabbits and dogs. However, the BA in monkeys was $18 \%$, lower than those of the other animal species. The $\mathrm{C}_{\max }$ of $\mathrm{NK}-104$ lactone after administration at $1 \mathrm{mg} / \mathrm{kg}$ was very low $(9.4 \mathrm{ng} / \mathrm{m} l)$.

3) Urinary and Fecal Excretion in Animals

Fig. 4 shows the excretion ratio of NK-104 in the urine and feces up to 72 or $96 \mathrm{~h}$ after intravenous administration at a dose of $0.1-1.0 \mathrm{mg} / \mathrm{kg}$, and after oral administration at a dose of $1 \mathrm{mg} / \mathrm{kg}$ to the four animal species. The excretion was nearly complete in the first $24 \mathrm{~h}$ after administration (data not shown). After oral administration, the drug was excreted mainly into feces in rats and dogs as the unchanged form, accounting for 61.6 and $46.2 \%$ of the dose, respectively. The urinary excretions were practically negligible in both species, indicating less than $1 \%$ of the dose. The NK-104 was excreted mainly into urine in rabbits (35.7\% of dose), while the fecal excretion was only $13.0 \%$ of dose. The excretion of unchanged NK-104 in monkeys was slight, being 0.1 and $5.2 \%$ of the dose into urine and feces, respectively.

The NK-104 lactone and the glucuronic acid conjugates of NK-104 and NK-104 lactone were excreted at less than $5 \%$ of the dose in all species after oral administration. In addition, no essential changes were noted in the excretion ratio at any dose after oral administration of NK-104 (data not shown). After intravenous administration, the urinary and fecal excretions of NK104, NK-104 lactone and the glucuronic acid conjugates were similar to those in the oral dose study in all species.

\section{Biliary Metabolites in Rats (Table IV)}

In bile, the unchanged NK-104 accounted for 32.3\% of the dose. The metabolites of NK-104, M-3 (5-keto NK-104), NK-104 lactone, M-11 (taurine conjugate of pentenoic acid derivative), M-10 (taurine conjugate of pentadienoic acid derivative) and $\mathrm{M}-6$ (pentenoic acid 

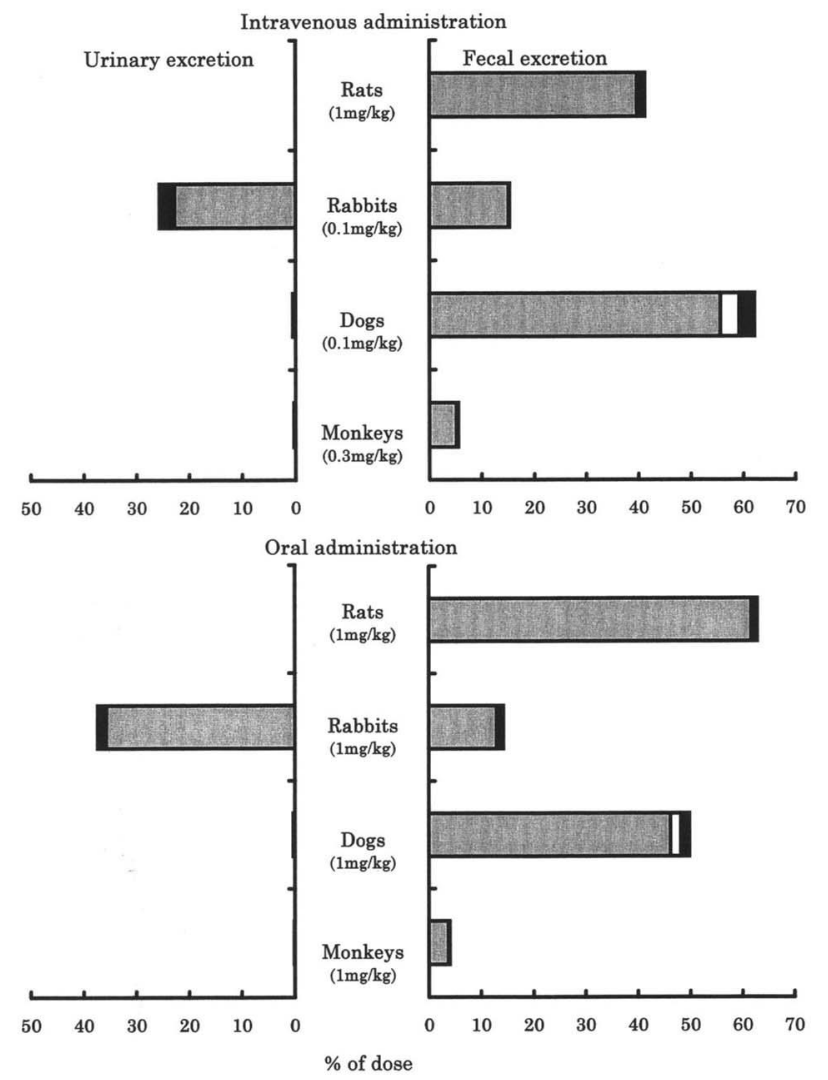

Fig. 4 Urinary and fecal excretions of NK-104, NK-104 conjugate and Lactone after intravenous and oral administration of $\mathrm{NK}-104$ at a dose of $0.1-1 \mathrm{mg} / \mathrm{kg}$ to different species

圆: NK-104 $\square$ : Lactone $\square$ : NK-104 conjugate
Table IV Composition of NK-104 and its metabolites in bile after oral administration at dose of $1 \mathrm{mg} /$ $\mathrm{kg}$ to rats

\begin{tabular}{lcc}
\hline & \multicolumn{2}{c}{ Composition (\% of dose) } \\
\hline & Unconjugate & Conjugate \\
\hline NK-104 & $32.27 \pm 4.73$ & $0.32 \pm 0.20$ \\
Lactone & $5.56 \pm 1.29$ & $0.10 \pm 0.10$ \\
M-2 & 0.00 & $0.02 \pm 0.02$ \\
M-3 & $7.08 \pm 0.85$ & $1.01 \pm 0.35$ \\
M-4 & $0.12 \pm 0.02$ & $0.01 \pm 0.00$ \\
M-5 & 0.00 & $0.34 \pm 0.01$ \\
M-6 & $1.52 \pm 0.38$ & $11.22 \pm 1.32$ \\
M-7 & $0.25 \pm 0.02$ & 0.00 \\
M-8 & $0.07 \pm 0.04$ & $0.02 \pm 0.02$ \\
M-9 & 0.00 & 0.00 \\
M-10 & & $1.97 \pm 0.21$ \\
M-11 & & $3.07 \pm 0.49$ \\
\hline Total recovery & $64.96 \pm 5.97$ & \\
\hline
\end{tabular}

Each value represents the mean \pm S.E. of five rats.

derivative) accounted for 7.1, 5.6, 3.1, 2.0 and 1.5\% of the dose, respectively. M-7 (hydroxypentenoic acid derivative) and M-8 (propenoic acid derivative) accounted for less than $0.3 \%$ of the dose. After the enzymatic hydrolysis of bile, $\mathrm{M}-6$ accounted for $11.2 \%$ of the dose. The other glucuronic acid conjugate metabolites accounted for less than 1.0\%. No other metabolites were determined in rat bile. The total recovery of NK104 and its metabolites was about $65 \%$ of the dose up to $24 \mathrm{~h}$.
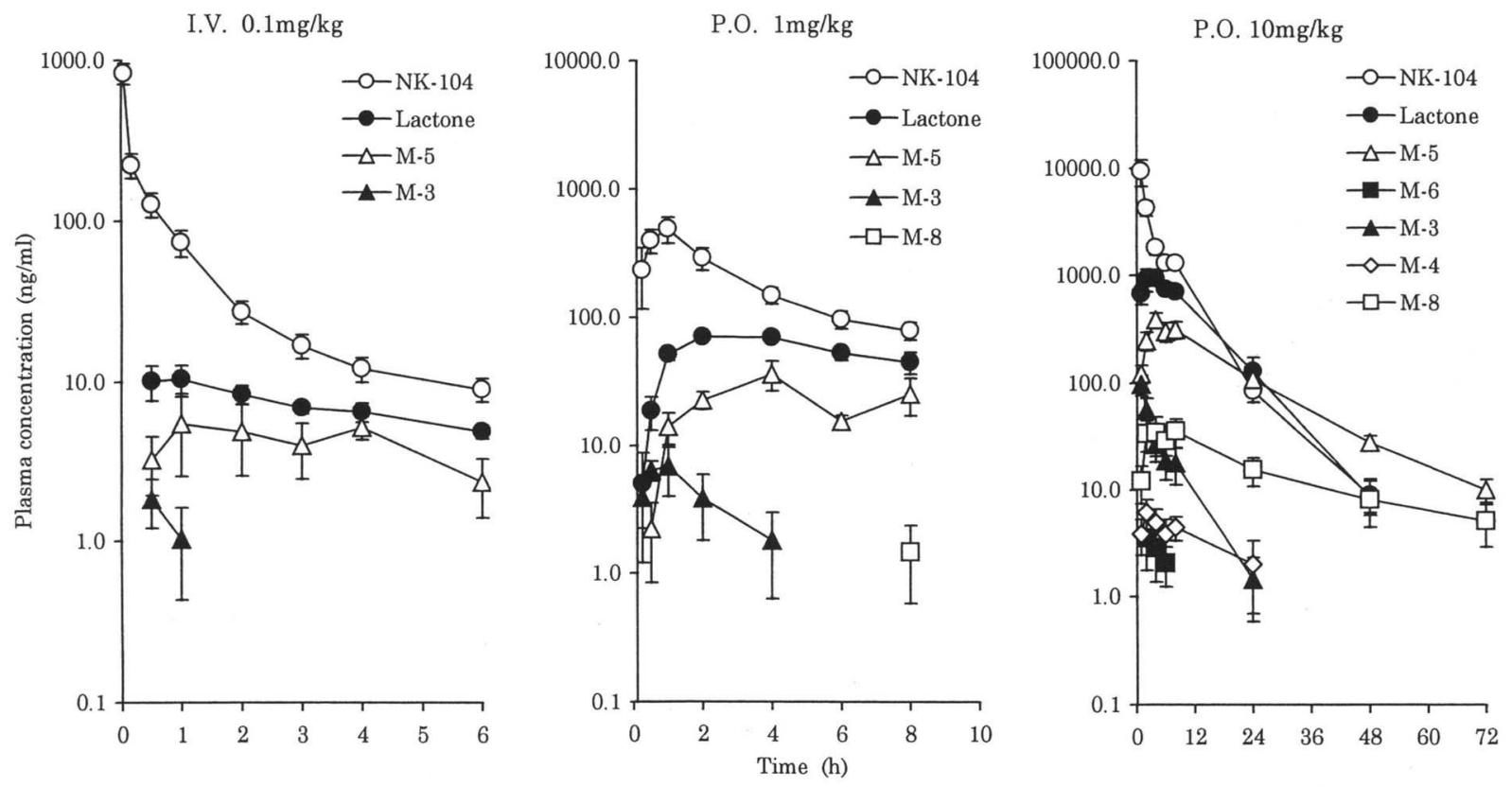

Fig. 5 Mean plasma concentration of NK-104 and its metabolites after intravenous $(0.1 \mathrm{mg} / \mathrm{kg}$ ) or oral administration (1 $\mathrm{mg} / \mathrm{kg}$ and $10 \mathrm{mg} / \mathrm{kg}$ ) of $\mathrm{NK}-104$ to dogs Each point represents the mean \pm S.E of four dogs. 
Table V Pharmacokinetic parameters of NK-104 and its metabolites after intravenous or oral administration of NK-104 to dogs

\begin{tabular}{|c|c|c|c|c|c|}
\hline \multicolumn{2}{|c|}{ Parameter } & $\underset{(\mathrm{ng} / \mathrm{m} l)}{\mathrm{C}_{\max }}$ & $\begin{array}{l}\mathrm{T}_{\max } \\
(\mathrm{h})\end{array}$ & $\underset{(\mu \mathrm{g} \cdot \mathrm{h} / \mathrm{m} l)}{\mathrm{AUC}}$ & $\begin{array}{l}t_{1 / 2} \\
(h)\end{array}$ \\
\hline \multirow{4}{*}{ I.V. $0.1 \mathrm{mg} / \mathrm{kg}$} & NK-104 & - & - & $0.398 \pm 0.037$ & - \\
\hline & Lactone & $11.0 \pm 2.2$ & $1.0 \pm 0.4$ & $0.042 \pm 0.006$ & - \\
\hline & $\mathrm{M}-3$ & $1.8 \pm 0.6$ & $0.5 \pm 0.0$ & $0.002 \pm 0.001$ & - \\
\hline & $\mathrm{M}-5$ & $7.4 \pm 2.3$ & $1.9 \pm 0.8$ & $0.025 \pm 0.008$ & - \\
\hline \multirow{4}{*}{ P.O. $1 \mathrm{mg} / \mathrm{kg}$} & NK-104 & $526 \pm 107$ & $0.8 \pm 0.2$ & $1.59 \pm 0.27$ & - \\
\hline & Lactone & $72.8 \pm 2.4$ & $2.5 \pm 0.5$ & $0.44 \pm 0.03$ & - \\
\hline & $\mathrm{M}-3$ & $8.6 \pm 2.4$ & $0.7 \pm 0.2$ & $0.02 \pm 0.01$ & - \\
\hline & $\mathrm{M}-5$ & $36.4 \pm 9.5$ & $4.0 \pm 0.0$ & $0.17 \pm 0.03$ & - \\
\hline \multirow{7}{*}{ P.O. $10 \mathrm{mg} / \mathrm{kg}$} & NK-104 & $9509 \pm 2488$ & $1.3 \pm 0.3$ & $35.48 \pm 4.32$ & $5.56 \pm 0.47$ \\
\hline & Lactone & $1013 \pm 177$ & $4.0 \pm 1.4$ & $14.50 \pm 1.65$ & $5.76 \pm 0.97$ \\
\hline & M-3 & $96.9 \pm 21.0$ & $1.0 \pm 0.0$ & $0.46 \pm 0.14$ & - \\
\hline & M-4 & $6.7 \pm 1.4$ & $3.5 \pm 1.5$ & $0.11 \pm 0.04$ & - \\
\hline & M-5 & $400 \pm 57$ & $6.0 \pm 1.2$ & $7.57 \pm 0.85$ & $13.8 \pm 0.85$ \\
\hline & M-6 & $4.0 \pm 1.4$ & $2.5 \pm 0.5$ & $0.04 \pm 0.03$ & - \\
\hline & M-8 & $39.9 \pm 10.6$ & $4.5 \pm 1.3$ & $1.07 \pm 0.32$ & $28.4 \pm 4.29$ \\
\hline
\end{tabular}

The data are expressed as mean \pm S.E. of four dogs.

\section{Plasma Metabolites in Dogs (Fig. 5, Table V)}

After intravenous administration, the unchanged NK104 was mainly found in the plasma and showed a triexponential elimination. The AUC values of NK-104, NK104 lactone, M-5 (pentadienoic acid derivative) and M3 were $0.398,0.042,0.025$ and $0.002 \mu \mathrm{g} \mathrm{h} / \mathrm{ml}$, respectively. After oral administration at a dose of $1 \mathrm{mg} / \mathrm{kg}$, the parent drug appeared rapidly in plasma, and the $\mathrm{C}_{\max }$ was $526 \mathrm{ng} / \mathrm{ml}$. The AUC values of $\mathrm{NK}-104, \mathrm{NK}-104$ lactone, $\mathrm{M}-5$ and $\mathrm{M}-3$ were $1.59,0.44,0.17$ and $0.02 \mu \mathrm{g}$ $\mathrm{h} / \mathrm{ml}$, respectively. At a dose of $10 \mathrm{mg} / \mathrm{kg}$, the AUC of $\mathrm{NK}-104$, lactone and $\mathrm{M}-5$ were $35.5,14.5$ and $7.6 \mu \mathrm{g} \mathrm{h} /$ $\mathrm{m} l$, respectively. Moreover, the $\mathrm{t}_{1 / 2}$ of $\mathrm{M}-5$ was $13.8 \mathrm{~h}$. The concentrations of $\mathrm{M}-3, \mathrm{M}-4, \mathrm{M}-6$ and $\mathrm{M}-7$ were also detected as minor metabolites. Although M-8 was also a minor metabolite, the $t_{1 / 2}$ was $28.4 \mathrm{~h}$. No other metabolites were found in dog plasma at any dosing.

\section{Urinary and Fecal Metabolites in Dogs (Table VI)}

The unchanged NK-104 was excreted mainly in feces after intravenous and oral administrations to dogs. After intravenous administration at a dose of $0.1 \mathrm{mg} / \mathrm{kg}$, the unchanged NK-104 in feces was $31.1 \%$ of the dose. The excretions of $\mathrm{M}-5$ and $\mathrm{NK}-104$ lactone were 2.2 and $0.3 \%$ of the dose, respectively. The total recovery of NK-104 and metabolites reached about $34 \%$ of the dose. The excretions of NK-104 after oral administration at $1 \mathrm{mg} / \mathrm{kg}$ and $10 \mathrm{mg} / \mathrm{kg}$ were 49.9 and $38.7 \%$; those of $\mathrm{NK}-104$ lactone were 2.6 and $2.3 \%$, and those of $\mathrm{M}-5$ were 1.7 and $1.8 \%$ of the dose. $\mathrm{M}-2$ (NK-104 dehydrolactone), M-3, M-4, M-6, M-7 and M-8 were slightly detected in feces; the excretion ratios were less than $0.3 \%$ of the dose. No other metabolites were detected in the feces. The total recovery of NK-104 and its metabolites at $1 \mathrm{mg} / \mathrm{kg}$ and $10 \mathrm{mg} / \mathrm{kg}$ was about 55 and
$44 \%$ of the dose, respectively. The urinary excretion of $\mathrm{NK}-104$ at both doses was less than $0.2 \%$ of the dose, and the excretions of metabolites were negligible. After enzymatic hydrolysis, no marked difference was noted in the relative amounts of NK-104 and its metabolites in the urine and feces (data not shown).

\section{Repeated Administration of NK-104 to Humans (Fig. 6, Table VII) \\ After repeated oral administration of NK-104 to hu-} mans, the unchanged $\mathrm{NK}-104$ appeared rapidly in the plasma. The $\mathrm{C}_{\max }$ value of $\mathrm{NK}-104$ was $36.3 \mathrm{ng} / \mathrm{ml}$ on day 1 , and slightly increased to the $\mathrm{C}_{\max }$ of $41.4 \mathrm{ng} / \mathrm{ml}$ on day 5. Subsequently, the concentration of NK-104 declined with the $t_{1 / 2}$ of $13.1 \mathrm{~h}$. NK-104 lactone was found in plasma as a major metabolite of $\mathrm{NK}-104$. The $\mathrm{C}_{\max }$ value of $\mathrm{NK}-104$ lactone was $19.5 \mathrm{ng} / \mathrm{m} l$ on day 1 , and the $\mathrm{C}_{\max }$ of $21.5 \mathrm{ng} / \mathrm{m} l$ was observed on day 5 . Subsequently, the concentration of NK-104 lactone decreased with the $t_{1 / 2}$ of $12 \mathrm{~h}$ on day 5 . Due to the repeated administration, the AUC values of $\mathrm{NK}-104$ and NK-104 lactone on day 5 were increased by about $20 \%$ compared to day 1 . M-9 was slightly detected at 6 and $24 \mathrm{~h}$ on day 5 , whereas the level of M-9 was negligible. No other metabolites were detected in human plasma during the repeated administration (data not shown). Moreover, no remarkable difference was observed in the other pharmacokinetic parameters during the repeated oral administration.

\section{Urinary Metabolites in Humans (Table VIII)}

The urinary excretions of NK-104 and NK-104 lactone were $0.7 \%$ and $1.7 \%$ of the dose, respectively. The excretion of $\mathrm{M}-2$ was slight in urine $(0.1 \%$ of the dose). No other metabolites were detected in human urine dur- 
Table VI Mean urinary and fecal excretion ratios of NK-104 and its metabolites after intravenous or oral administration of NK104 at a dose of $0.1-10 \mathrm{mg} / \mathrm{kg}$ to $\operatorname{dogs}$

\begin{tabular}{|c|c|c|c|c|}
\hline \multirow{2}{*}{\multicolumn{2}{|c|}{ Metabolite }} & \multicolumn{3}{|c|}{ Mean excretion ratio (\% of dose) } \\
\hline & & Urine & Feces & Total \\
\hline \multirow{4}{*}{$0.1 \mathrm{mg} / \mathrm{kg}$} & NK-104 & $0.00 \pm 0.00$ & $31.13 \pm 0.70$ & 31.13 \\
\hline & Lactone & $0.00 \pm 0.00$ & $0.31 \pm 0.31$ & 0.31 \\
\hline & $\mathrm{M}-5$ & $0.00 \pm 0.00$ & $2.22 \pm 1.28$ & 2.22 \\
\hline & Total recovery & & & 33.65 \\
\hline \multirow{7}{*}{$1 \underset{(\mathrm{p} . \mathrm{o} .)}{\mathrm{mg} / \mathrm{kg}}$} & NK-104 & $0.18 \pm 0.06$ & $49.92 \pm 5.69$ & 50.10 \\
\hline & Lactone & $0.00 \pm 0.00$ & $2.59 \pm 0.34$ & 2.59 \\
\hline & M-2 & $0.00 \pm 0.00$ & $0.03 \pm 0.03$ & 0.03 \\
\hline & $\mathrm{M}-3$ & $0.00 \pm 0.00$ & $0.19 \pm 0.05$ & 0.19 \\
\hline & $M-5$ & $0.00 \pm 0.00$ & $1.73 \pm 0.11$ & 1.73 \\
\hline & $\mathrm{M}-8$ & $0.00 \pm 0.00$ & $0.07 \pm 0.04$ & 0.07 \\
\hline & Total recovery & & & 54.71 \\
\hline \multirow{10}{*}{$10 \underset{\text { (p.o.) }}{\mathrm{mg} / \mathrm{kg}}$} & NK-104 & $0.16 \pm 0.05$ & $38.71 \pm 3.36$ & 38.86 \\
\hline & Lactone & $0.00 \pm 0.00$ & $2.28 \pm 0.07$ & 2.28 \\
\hline & M-2 & $0.00 \pm 0.00$ & $0.19 \pm 0.02$ & 0.19 \\
\hline & M-3 & $0.01 \pm 0.01$ & $0.25 \pm 0.10$ & 0.26 \\
\hline & M-4 & $0.00 \pm 0.00$ & $0.03 \pm 0.03$ & 0.03 \\
\hline & M-5 & $0.02 \pm 0.02$ & $1.76 \pm 0.11$ & 1.78 \\
\hline & $\mathrm{M}-6$ & $0.00 \pm 0.00$ & $0.09 \pm 0.03$ & 0.09 \\
\hline & $\mathrm{M}-7$ & $0.00 \pm 0.00$ & $0.01 \pm 0.01$ & 0.01 \\
\hline & M-8 & $0.00 \pm 0.00$ & $0.29 \pm 0.06$ & 0.29 \\
\hline & Total recovery & & & 43.78 \\
\hline
\end{tabular}

Each value represents the mean \pm S.E. of four dogs.

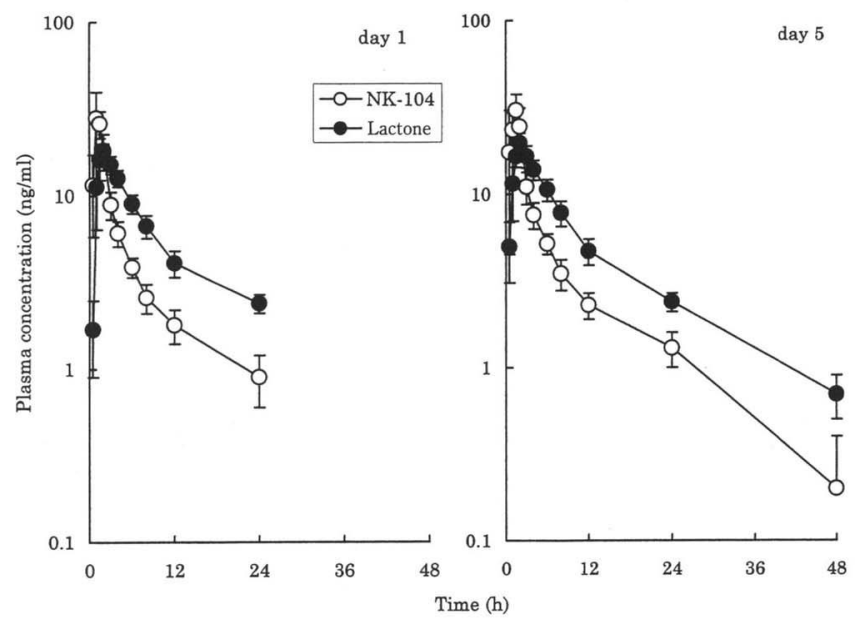

Fig. 6 Mean plasma concentration of NK-104 (O) and NK104 lactone ( ) after repeated oral administrations of NK-104 at a dose of $2 \mathrm{mg}$ once a day for 5 days to human subjects

Each point represents the mean \pm S.E of six male subjects.
Table VII Pharmacokinetic paramerters of NK-104 and lactone after repeated oral administration of NK-104 at a dose of $2 \mathrm{mg}$ once a day for five days to subjects

\begin{tabular}{llcc}
\hline & & Day-1 & Day-5 \\
\hline NK-104 & $\mathrm{T}_{\max }(\mathrm{h})$ & $1.2 \pm 0.1$ & $1.2 \pm 0.2$ \\
& $\mathrm{C}_{\max }(\mathrm{ng} / \mathrm{m} l)$ & $36.3 \pm 8.5$ & $41.4 \pm 9.0$ \\
& $\mathrm{AUC}(\mathrm{ng} . \mathrm{h} / \mathrm{m} l)$ & $99.8 \pm 19.3$ & $123.4 \pm 22.2$ \\
& $\mathrm{t}_{1 / 2}(\mathrm{~h})$ & - & $13.1 \pm 1.4$ \\
\hline Lactone & $\mathrm{T}_{\max }(\mathrm{h})$ & $1.7 \pm 0.1$ & $1.6 \pm 0.2$ \\
& $\mathrm{C}_{\max }(\mathrm{ng} / \mathrm{m} l)$ & $19.5 \pm 2.6$ & $21.5 \pm 2.7$ \\
& $\mathrm{AUC}(\mathrm{ng} . \mathrm{h} / \mathrm{m} l)$ & $147.0 \pm 19.0$ & $166.1 \pm 23.2$ \\
& $\mathrm{t}_{1 / 2}(\mathrm{~h})$ & - & $12.0 \pm 1.1$ \\
\hline
\end{tabular}

Each value represents mean \pm S.E. of five human. 
Table VIII Urinary excretion of NK-104 and its methabolites after repeated oral administration of NK-104 $2 \mathrm{mg}$ once a day for five days to subjects

\begin{tabular}{lc}
\hline & $\begin{array}{c}\text { Cumulative excretion } \\
(\% \text { of dose) }\end{array}$ \\
\hline NK-104 & $0.67 \pm 0.13$ \\
Lactone & $1.67 \pm 0.35$ \\
M-2 & $0.13 \pm 0.07$ \\
M-3 & $0.00 \pm 0.00$ \\
M-4 & $0.00 \pm 0.00$ \\
M-5 & $0.00 \pm 0.00$ \\
M-6 & $0.00 \pm 0.00$ \\
M-7 & $0.00 \pm 0.00$ \\
M-8 & $0.00 \pm 0.00$ \\
M-9 & $0.00 \pm 0.00$ \\
M-10 & $0.00 \pm 0.00$ \\
M-11 & $0.00 \pm 0.00$ \\
Conjugate* & $4.01 \pm 0.33$ \\
\hline
\end{tabular}

Each value represents mean \pm S.E. of five human.

* : Glucronic acid conjugate of NK-104 and NK-104 lactone.

ing the repeated administration. After enzymatic hydrolysis, the total excretion ratio of the glucuronic acid conjugate of NK-104 and NK-104 lactone was about 4\% of the dose.

\section{Discussion}

In the present study, the interspecies variation on the pharmacokinetics and metabolism of NK-104 was investigated after intravenous and/or oral administration to animals and humans.
The plasma concentration of unchanged NK-104 and its lactone form after an intravenous administration to rats, rabbits, dogs and monkeys decreased triexponentially, and the terminal half-life $\left(t_{1 / 2}\right)$ values were about $5 \mathrm{~h}$ in all species. The distribution volumes of steadystate (Vss) and the plasma clearance (Clp) values showed a large difference. Therefore, marked species differences were observed in the distribution into systemic tissues, and in the systemic clearance.

After oral administration, NK-104 was well absorbed and the $t_{1 / 2}$ of the terminal phase in each species was similar to that after intravenous administration. Moreover, high bioavailability (BA) was observed in all species except monkeys. The relationship between oral dosage and AUC was apparent linear in the relatively high dose range in all species; however, the correlation lines were not extrapolated through the origin. Moreover, the improvement of BA was observed as the increase of dose in all species except monkeys. These results indicated that the saturated metabolism might affect the plasma concentration of minimum dose after oral administration. On the other hand, the results previously reported for humans, ${ }^{7)}$ are presented in Fig. $\mathbf{7}$ for comparison with these animal data. The correlation line for humans was well extrapolated through the origin, even at the low dosage. The correlation line for humans was located between those of dogs and rats. In addition, $\mathrm{NK}-104$ lactone was found in the plasma of dogs and humans as the major metabolite of this drug, suggesting that the pharmacokinetics of NK-104 in humans resemble those in dogs. We expected that the monkeys would show the pharmacokinetic model most similar to that of humans. In the monkeys, however, that NK-104 may be

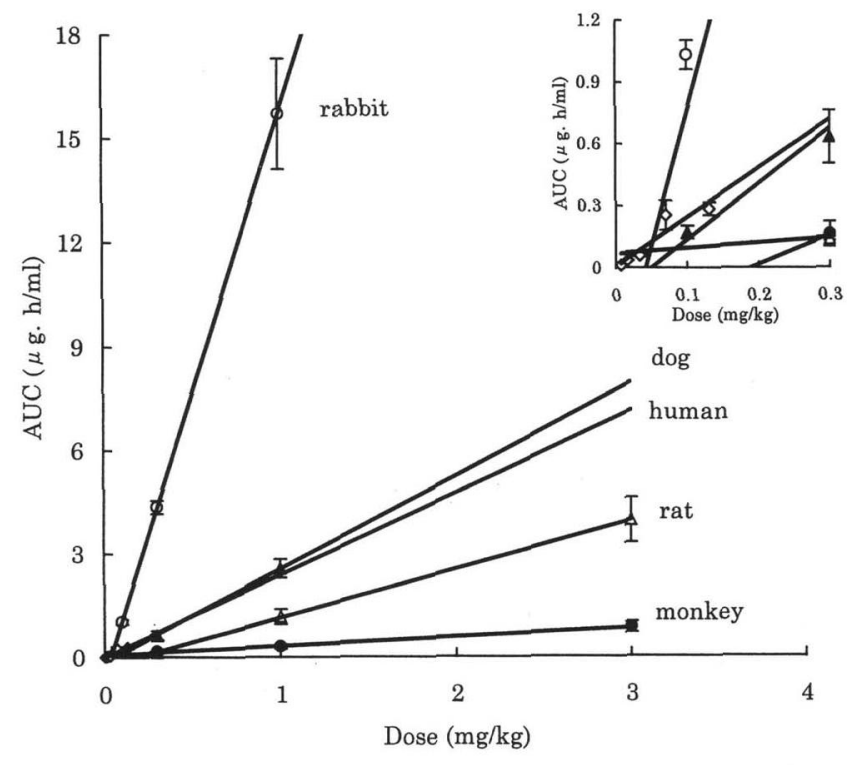

Fig. 7 Relationships between area under the curve of the plasma concentration of NK-104 and dose in rats $(\triangle)$, rabbits $(\bigcirc), \operatorname{dogs}(\mathbf{\Delta})$, monkeys $(\boldsymbol{O})$ and humans $(\diamond)$

Each point represents the mean \pm S.E of $3-6$ animals or humans. Human data were quoted from a phase-one clinical study ${ }^{7)}$. 
most markedly metabolized compared with the other animal models. In particular, the pharmacokinetic parameters of the AUC and BA in monkeys showed significantly lower values than in other species.

It has been reported that the $\mathrm{BA}$ of other $\mathrm{HMG}-\mathrm{CoA}$ reductase inhibitors (statins), i.e, pravastatin, fluvastatin, and cerivastatin, was 37, 41 and 67\%, respectively, ${ }^{8-10)}$ in dogs. The BA of fluvastatin and cerivastatin in rats was $46 \%$ and $26 \%$, respectively. ${ }^{10,11)}$ However, the BA of NK-104 at $1 \mathrm{mg} / \mathrm{kg}$ was considerably high in dogs and rats of the present study (80\% or more) compared with other statins. We suspect that NK-104 was excreted mainly into bile as the unchanged form and was reabsorbed by the entero-hepatic circulation, suggesting that the apparent BA of NK-104 in animals was high.

The lactone form of NK-104 was not detected in plasma after intravenous and oral administrations of NK104 to rats; however, this metabolite was determined although at significantly lower levels than the parent drug in plasma of rabbits, dogs, and monkeys. In humans, the $\mathrm{C}_{\max }$ of $\mathrm{NK}-104$ lactone showed a level of approximately half in comparison with the parent drug, indicating that lactonization was the major metabolic pathway. Interestingly, the lactonization of $\mathrm{NK}-104$ is a dehydrated reaction unparticipating with cytochrome $\mathrm{P}-$ 450 enzymes. Since the HMG - CoA reductase inhibitors, lovastatin and simvastatin are lactone prodrugs that become active inhibitors upon hydrolytic conversion, ${ }^{12)}$ NK-104 lactone would be reversibly converted to NK104 in humans.

The total excretion ratio of $\mathrm{NK}-104$ and its lactone reached more than $40 \%$ of the dose independently of on the administration route in all animal species tested here except monkeys. In addition, the main excretion pathway of NK-104 in rabbits was the renal route. It has been also reported that several other statins are mainly excreted via bile in most animal species. ${ }^{11,13)}$ However, the urinary excretion of ${ }^{14} \mathrm{C}$-fluvastatin in rabbits reached about $32 \%$ of the total radioactivity. ${ }^{14)}$ These results suggest that the renal route may be a major excretion pathway of statins in rabbits. In rats and dogs, the unchanged NK-104 was excreted mainly in feces. The urinary excretion rates of NK-104 and NK-104 lactone in both species were low (less than $2 \%$ of the dose), indicating that the urinary excretion pattern in both rats and dogs resembles that in humans, suggesting that NK-104 may be excreted in feces via biliary excretion in humans.

We have previously reported that the biliary excretion of ${ }^{14} \mathrm{C}-\mathrm{NK}-104$ was $75 \%$ up to $48 \mathrm{~h}$ after oral administration in rats and that most of this drug was subjected to entero-hepatic circulation. ${ }^{2}$ The remarkable inhibitory effect of sterol synthesis in rat was observed until $6 \mathrm{hr}$ after administration of $\mathrm{NK}-104$ and the concentration of unchanged NK-104 in liver was about 70-fold higher than that in plasma. ${ }^{1)}$ These results suggested that the entero-hepatic circulation of $\mathrm{NK}-104$ related to the duration of drug effect. The metabolic pattern in rat bile was further examined in the present study. The unchanged $\mathrm{NK}-104$ accounted for $32 \%$ of the dose in bile until $24 \mathrm{~h}$ after administration. On the other hand, the metabolites of NK-104 were also excreted in bile. Moreover, NK104 and its metabolites were detected in dog feces, indicating that elimination pathway of this drug and metabolites were hepatobiliary excretion. It was recently reported that the carrier-mediated transporter contributes to the hepatobiliary excretion of many drugs. ${ }^{15)}$ In particular, a primary active transport mechanism has been shown to be responsible for the biliary excretion of organic anions including glucuronic acid conjugates. ${ }^{16,17)}$ Therefore, some metabolites of NK104 are probably eliminated by the hepatobiliary transport mechanism because these metabolites are also organic anions as well as $\mathrm{NK}-104$.

We also investigated the metabolic patterns of NK104 in plasma of dogs; these patterns resemble the NK104 pharmacokinetics in humans. No marked difference was observed in the ratios of metabolites between intravenous and oral administrations to dogs. The ratios occupied by the unchanged NK-104 in plasma after administration to dogs were much higher than those of every metabolite. NK-104 lactone and M-5 were detected as minor metabolites. In addition, $\mathrm{M}-5$ and $\mathrm{M}-8$, which were formed at the latter stage of the metabolic pathway, were maintained up to $8 \mathrm{~h}$, and their elimination was also considerably slow at a dose of $10 \mathrm{mg} / \mathrm{kg}$. These results suggest that although NK-104 was scarcely metabolized in dogs, the elimination rates of minor metabolites ( $M-5$ and $M-8$ ) were lower than that of NK-104.

The $\mathrm{M}-5$ and $\mathrm{M}-8$ metabolized from NK-104 are products of $\beta$-oxidation of the heptenoic side chain, and they possess a mono-carboxylate moiety. It has been reported that the mono-carboxylate transport system plays important roles in the transport of short-chain mono-carboxylic acids at the plasma membrane of the heart and skeletal muscle. ${ }^{18,19)}$ Since the retention of $\mathrm{M}$ 6 and $\mathrm{M}-8, \beta$-oxidation products of $\mathrm{NK}-104$, has been previously observed in these tissues of rats, ${ }^{2)}$ we suggest that $\mathrm{M}-5$ and $\mathrm{M}-8$ in plasma of dogs also may be transported across the plasma membrane via the monocarboxylate transporter in the heart and skeletal muscle.

In the present study, we also determined NK-104 and its metabolites in plasma and urine after a repeated oral administration to healthy human volunteers at $2 \mathrm{mg} / \mathrm{sub}$ ject once a day for 5 days. The variations of inter-AUC and inter- $\mathrm{C}_{\max }$ of NK-104 in humans were about 3 folds. However, no marked difference was noted between the humans and animals in the variation of inter-plasma concentration. After this oral administration to humans, the unchanged NK-104 and its lactone were mainly observed in plasma. On the other hand, a slight amount of metabolites were detected. These findings suggest that 
NK-104 is hardly metabolized in the human liver more than in each animal species. The $t_{1 / 2}(13.1 \mathrm{~h})$ of the terminal phase in humans was thus longer than those in the animal species studied (4-7 h) and these results indicated that NK-104 was subjected to entero-hepatic circulation in human.

Compared with the biotransformation of other statins, lovastatin was extensively metabolized by two major pathways, namely the cytochrome $\mathrm{P}-450$-mediated oxidation of the fused-ring system and the $\beta$-oxidation of the heptanoic acid side chain after hydrolysis of the lactone ring. ${ }^{20)}$ Fluvastatin was completely metabolized by the hydroxylation of the indole ring, the loss of the 1isopropyl group, $\beta$-oxidation, lactone formation, the formation of the threo-isomer and conjugation with glucuronic acid or sulfate. ${ }^{21)}$ In contrast, pravastatin was metabolized by $\beta$-oxidation, lactone formation, isomerization and conjugation with glutathione. ${ }^{13)}$ It has been reported that cerivastatin is also susceptible to being metabolized by cytochrome $\mathrm{P}-450$-mediated hydroxylation and $\beta$-oxidation. ${ }^{22)} \mathrm{A}$ remarkable difference was observed in the metabolic pathway between NK-104 and other statins in the ring hydroxylation, which is the major metabolic pathway of other statins.

We therefore find that the most interesting features of NK-104 is that it is hardly metabolized via cytochrome $\mathrm{P}-450$ mediated oxidation and/or $\beta$-oxidation in humans. The pharmacokinetic properties of NK-104 in humans are good absorption, a relatively long $t_{1 / 2}$ and possibly high bioavailability. We speculated that these favorable metabolic and pharmacokinetic characteristics of this drug support efficacy in clinical studies ${ }^{23,24)}$ as a hypolipidemic and antiatherosclerotic agent in humans.

Acknowledgement: The authors would like to thank Drs. M. Yoshimura, T. Koide, M. Yonemitsu, Y. Tsunenari and N. Saito for their technical support during this study.

\section{References}

1) Aoki T., Nishimura H., Nakagawa S., Kojima J., Suzuki H., Tamaki T., Wada Y., Yokoo N., Sato F., Kimata H., Kitahara M., Toyoda K., Sakashita M. and Saito Y.: Pharmacological profile of a novel synthetic inhibitor of 3hydroxy-3-methylglutaryl-coenzyme A reductase. Arzneim. Forsch./Drug Res., 47 (8): 904-909 (1997).

2) Kimata H., Fujino H., Koide T., Yamada Y., Tsunenari Y. and Yanagawa Y.: Studies on the metabolic fate of NK104, a new inhibitor of HMG CoA reductase (1): Absorption, distribution, metabolism and excretion in rats. Xeno. Metab. Disp., 13(5): 484-498 (1998).

3) Fujino H., Tsunenari Y., Koide T., Yonemitsu M., Yanagawa Y. and Kimata H.: Studies on the metabolic fate of NK-104, a new inhibitor of HMG-CoAreductase (2): Absorption, distribution, metabolism, excretion and accumulation following repeated oral administration of ${ }^{14} \mathrm{C}-\mathrm{NK}-104$ in rats. Xeno. Metab. Disp., 13(5): 499-507
(1998).

4) Kojima J., Fujino H., Abe H., Yoshimura M., Kanda H. and Kimata H.: Identification of metabolites of NK-104, an $\mathrm{HMG}-\mathrm{CoA}$ reductase inhibitor, in rat, rabbit and dog bile. Biol. Pharm. Bull., 22 (2): 142-150 (1999).

5) Kojima J., Fujino H., Yoshimura M., Morikawa H. and Kimata H.: Simultaneous determination of NK-104 and its lactone in biological samples by column switching high-performance liquid chromatography and ultraviolet detection. J. Chromatogr. (B), 724: 173-180 (1999).

6) Yamaoka K., Tanigawara Y., Nakagawa T. and Uno T.: A pharmacokinetic analysis program (MULTI) for microcomputer. J. Pharmacobio. Dyn., 4: 879-885 (1981).

7) Kimata H., Kojima J., Fujino H., Koide T., Yamada Y., Yoshimura M., Nakabeppu H., Nakaya N. and Saito Y.: Pharmacokinetics of NK-104 (nisvastatin) in animals and human. XIII International Symposium on Drug Affecting Lipid Metabolism. (Abstracts) 63 (1998) Florence, Italy.

8) Morrison R. A. and Singhvi S. M.: Pharmacokinetics and oral bioavailability of pravastatin in dogs. Int. J. Pharm., 143: 265-269 (1996).

9) Tse F. L. S., Smith H. T., Ballard F. H. and Nicoletti J.: Disposition of fluvastatin, an inhibitor of HMG-CoA reductase, in mouse, rat, dog, and monkey. Biopharm. Drug Dispos., 11: 519-531 (1990).

10) Steinke W., Yamashita S., Tabei M., Ahr H. J., Beckermann B., Domdey-Bette A., Göller G., Schwarz T. and Siefert H. M.: Cerivastatin, a new inhibitor of HMG-CoA reductase-pharmacokinetics in rats and dogs. Jpn. Pharmacol. Ther., (Suppl) 24: 1217-1237 (1996).

11) Masuda N., Akasaka I. and Ohtawa M.: Metabolic fate of fluvastatin, an inhibitor of HMG-CoA reductase (1): Absorption, distribution and excretion of ${ }^{14} \mathrm{C}$-fluvastatin after single administration in rats. Xeno. Metab. Disp., 10(4): 513-528 (1995).

12) Alberts A. W.: Lovastatin and simvastatin-inhibitor of HMG CoA reductase and cholesterol biosynthesis. Cardiology, (Suppl) 77(4): 14-21 (1990).

13) Komai T., Kawai K., Tokui T., Tokui Y., Kuroiwa C., Shigehara E. and Tanaka M.: Disposition and metabolism of pravastatin sodium in rats, dogs and monkeys. Eur. J. Drug Metab. Pharmacokinet., 17(2): 103-111 (1992).

14) Tse F. L. S. and Labbadia D: Absorption and disposition of fluvastatin, an inhibitor of HMG-CoA reductase, in the rabbit. Biopharm. Drug Dispos., 13: 285-294 (1992).

15) Yamazaki M., Nishigaki R., Suzuki H. and Sugiyama Y.: Kinetic analysis of hepatobiliary transport of drugs: Importance of carrier-mediated transport. Yakugaku Zasshi, 115(12): 953-977 (1995).

16) Suzuki H. and Sugiyama Y.: Role of transporters in the detoxification of xenobiotics: Recent advances in the study of cMOAT/MRP. Protein Nucleic Acid and Enzyme, 42 (8): 1273-1284 (1997).

17) Yamazaki M., Kobayashi K. and Sugiyama Y.: Primary active transport of pravastatin across the liver canalicular membrane in normal and mutant Esai hyperbilirubinaemic rats. Biopharm. Drug Dispos., 17: 645-659 (1996).

18) Tamai I.: Membrane transporters as determinant of drug absorption and disposition. Xeno. Metab. Disp., 11(6): 642-650 (1996)

19) Takanaga H., Tamai I., Inaba S., Sai Y., Higashida H., Yamamoto H. and Tsuji A.: cDNA cloning and functional 
characterization of rat intestinal monocarboxylate transporter. Biochem. Biophys. Res. Comm., 217(1): 370-377 (1995).

20) Halpin R. A., Ulm E. H., Till A. E., Kari P. H., Vyas K. P., Hunninghake D. B. and Duggam D. E.: Biotransformation of lovastatin; Species differences in in vivo metabolite profiles of mouse, rat, dog, and humans. Drug Metab. Dispos., 21: 1003-1011 (1993).

21) Dain J. G., Fu E., Gorski J., Nicoletti J. and Scallen T. J.: Biotransformation of fluvastatin sodium in humans. Drug Metab. Dispos., 21, 567-572 (1993).

22) Boberg M., Angerbauer R., Fey P., Kanhai W. K., Karl W., Kern A., Ploschke J. and Radtke M.: Metabolism of cerivastatin by human liver microsomes in vitro. Characterization of primary metabolic pathways and of cytochrome P450 isozymes involved. Drug Metab. Dispos., 25 (3): 321-331 (1997).

23) Kajinami K., Koizumi J., Miyamoto S., Takegoshi T. and Mabuchi H., and FH-NK-104 study group: Efficacy of NK-104 (nisvastatin), a new totally synthetic HMG-CoA reductase inhibitor, in heterozygous familial hypercholesterolemia. XIII International Symposium on Drug Affecting Lipid Metabolism. (Abstracts) 63 (1998) Florence, Italy.

24) Nakaya N., Kojima J., Kimata H., Kuwahata R. and Narushima H.: NK-104, efficacy and tolerance of a new synthetic HMG-CoA reductase inhibitor in hypercholesterolemic volunteers.. X International Symposium on Drug Affecting Lipid Metabolism. (Abstracts) 137 (1995) Houston, USA.

\section{正誤表}

Vol. 14, No. 2(1999)揭載論文中の“NK-104の体内動驡(4)，(PP79-91)”に誤りがありました。お詫びして訂正いたします.

\begin{tabular}{|c|c|c|c|c|}
\hline & & & 正 & 愦 \\
\hline \multicolumn{5}{|l|}{ Vol. 14 , No. 2} \\
\hline 81 頁 Table I 中 & 20 行目 & Method-3 Mobile phase & $(35: 65)$ & $(50: 50)$ \\
\hline 83 頁 Table II 中 & 8 行目 & Rat $\beta\left(\min ^{-1}\right)$ & $0.0038 \pm 0.0012$ & $0.0036 \pm 0.0011$ \\
\hline 84 頁 Table III 中 & 8 行目 & Rat $0.3 \mathrm{mg} / \mathrm{kg}$ & $\mathrm{n}=3$ & $\mathrm{n}=4$ \\
\hline 87 頁 Fig. 6 文章中 & 5 行目 & & five & $\operatorname{six}$ \\
\hline 88 頁 右段本文中 & 1 行目 & & NK-104 & NK-104 and its lactone form \\
\hline
\end{tabular}

